\title{
Emerging Countries as the Main Destinations for European Value-Added Exports
}

\section{Luisa Marti}

Universitat Politecnica de Valencia, Spain |

\section{Rosa Puertas}

Universitat Politecnica de Valencia, Spain | rpuertas@esp.upv.es

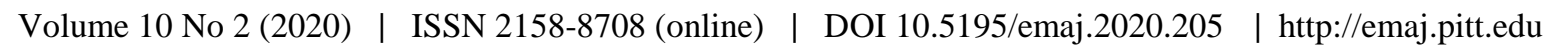

\section{Abstract}

Nowadays, production chains may cross the borders of several continents in search of greater profitability. In order to more accurately calculate countries' foreign demand, value-added exports should be used rather than gross exports. This study takes the value-added exports calculated for European Union countries and uses extended gravity models to analyze the determinants of this trade, differentiating between countries according to the main destinations for their value-added, USA, Russia and China. The results reveal certain changes according to the economic period analyzed and the destination of the goods, with respect to key variables such as the wealth of the exporting country, the level of logistics performance and distance. In 2014, China registered an improvement in its position compared to Russia.

Keywords: Emerging Countries, Global Value Chains, European Union, Gravity Models, Exports

\section{$(\mathrm{cc}) \mathrm{EY}$}

New articles in this journal are licensed under a Creative Commons Attribution 3.0 United States License.

\section{ULLS D-Surk}

This journal is published by the University Library System of the University of Pittsburgh as part

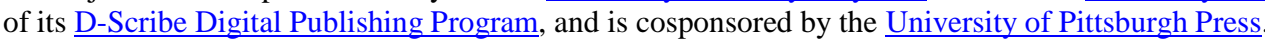




\section{Emerging Countries as the Main Destinations for European Value-Added Exports}

\section{Luisa Marti Rosa Puertas}

\section{Introduction}

Globalization, the expansion of world trade and offshoring are key elements of the 21 st century economy. Certain sophisticated products that would, in principle, be tied to developed countries are in fact the result of a production chain that crosses more than one border. The fragmentation of manufacturing processes is a modernday phenomenon and becoming increasingly widespread in all large companies. The initial design of the product, the manufacture of the constituent pieces, the assembly and even the sales processes make up a set of activities which are currently spread over a number of different continents, in search of greater specialization. It involves dividing up the production chain so that each link is produced in the best possible location, thus resulting in lower costs and products that are better adapted to the needs of the market.

This new state of affairs gives rise to the double counting problem associated with the exports; the statistical tools traditionally used have not been able to properly cope with this new production model (Leamer 2006, Grossman and Rossi-Hasberg 2008). Exported goods incorporate intermediate value-added, the origin of which lies among a number of different territories. As such, the monetary value assigned distorts the reality, which may lead to misinformed economic policy decisions. Hence, there is a need to analyze global value chains (GVCs) in order to determine each country's position and participation in the production process, which in turn will enable a more accurate identification of international trade patterns.

GVCs are defined as the set of activities encompassed in the production process of goods and services, divided into stages which are distributed between different countries. The most developed countries employ people specialized in research and development (R\&D), engineering and finance, among others; that is, high value-added jobs. This is not to belittle the contribution of developing countries, where the lower level of technical training required of workers comes with lower associated labor costs.

The first studies on the specialisation of countries emerged more than a decade ago with the pioneering work of Hummels et al. (2001). They suggested that a country can be involved in vertical specialization in two ways: using imported intermediate inputs to generate exports; and exporting intermediate goods that can be used as inputs in other countries to produce goods intended for international sale. These authors proposed the use of input-output tables (IOTs) to measure the part of total exports that had previously been imported and should be attributed to another country. However, the method rested on two assumptions that were soon contested by Koopman et al. (2008, 2012). They pointed out that the imported intermediate inputs were allocated in the same way regardless of whether the production was intended for export and for domestic sales; in addition, the method did not account the possibility of more than one country exporting intermediate goods. Koopman et al. (2010) constructs a GVC position index, which indicates whether a country specializes in the initial or the final stages of the production process.

International statistical agencies have proved unable to measure value-added trade, due to the difficulty of accessing information about these records. To this end, the literature proposes the use of international IOTs to build up a global picture of intersectoral trade relations between different economies. IOTs here are Global Trade Analysis Project (Narayanan and Walmsley 2008), World Input-Output database (Timmer 2012), OECDWTO TiVA, UNCTAD-Eora GVC database and IDEJETRO (Institute of Developing Economies - Japan External Trade Organisation). These tables enable a distinction to be made between the contribution of domestically-generated value-added to trade flows and that of foreign value-added. Following this line of thought, the studies of Daudin et al. (2011), Johnson and Noguera (2012) and Stehrer et al. (2012) propose the use of IOTs to determine the value-added of exports. For their part, Koopman et al. $(2010,2014)$ highlight the need to jointly analyze vertical specialization and valueadded trade. These two concepts provide the basis for a conceptual framework for decomposing a country's gross exports into the different elements of value-added, determining the impact of the double counting inherent in official trade statistics.

Against the backdrop of this innovative foreign trade research, the aims of this paper are as follows: (1) to calculate value-added exports in order to avoid double counting inherent in official trade statistics, using the methodology proposed by Koopman et al. (2014); (2) to identify the determinants of value-added exports from the European Union (EU) from its main trading partners, USA, Russia and China, by means of extended gravity equations. These equations incorporate a logistics component (Logistics Performance Index, LPI), which various authors such as Hertel and Mirza (2009), Felipe and Kumar (2012), Martí and Puertas (2017) among others have shown to be relevant in the analysis of bilateral international trade relations; (3) European countries are grouped according to the main destinations for their exports, to quantitatively verify whether this classification affects the explanatory variables for countries' trade in value-added. The analysis focuses on 2008 and 2014, two years marked by very different economic situations in Europe, to paint a broader picture of how economic circumstances affect trade relations.

The results provide new information contributing to the existing knowledge on international operations and can facilitate trade-policy decisionmaking. Replacing gross foreign sales with value-added exports, along with a specific analysis of the final destination for European goods, provides an accurate perspective of the relative importance of the explanatory 
variables for European trade. In addition, the two years under analysis, representing very different economic realities, enable an analysis of the possible link between changes in trade patterns and the period of the economic cycle in which they occur.

The rest of the paper is structured as follows: Section 2 explains the method used to determine valueadded exports and provides the results for the EU. Section 3 presents the gravity model developed in the empirical part of the paper. Section 4 analyzes the results regarding the determinants of European exports, differentiating between countries according to the destinations for their value-added trade. Section 5 summarizes the main conclusions.

\section{Extra-EU Trade: Value-Added Exports}

Official statistics overstate the bilateral trade by taking the final sale price instead of the value that is actually added in the country selling the product. In this regard, Dedrick et al. (2010) show how Chinese exports of Apple's iPod are computed according to their final sale price of $\$ 144$, despite the fact that less than $10 \%$ can be considered Chinese value-added, since the bulk of the component parts come from Japan, the USA or Korea. A new school of thought has thus emerged, comprising researchers who recommend using value-added exports rather than gross exports in the analysis of international trade, as the former provide a more accurate approximation of the real situation and change distorted trade patterns.

The value-added exports in this paper have been calculated using the method proposed by Koopman et al. (2014). It involves matrix calculations using international IOTs, which enables a determination of the value-added traded with third countries. The double counting problem inherent in official trade statistics can thus be avoided. This method has been used to compute EU-28 value-added exports to third countries corresponding to the years 2008 and 2014. The Table 1 shows both the absolute values and their rate of change, giving an initial indication of the degree of specialisation of these countries.
Table 1: EU-28 Value-Added Exports (in \$ millions)

\begin{tabular}{|l|r|r|r|}
\cline { 2 - 4 } \multicolumn{1}{l|}{} & $\mathbf{2 0 0 8}$ & $\mathbf{2 0 1 4}$ & Growth rate \\
\hline Estonia & 2,025 & 3,081 & $52.15 \%$ \\
\hline Lithuania & 3,796 & 5,548 & $46.15 \%$ \\
\hline Latvia & 1,738 & 2,524 & $45.22 \%$ \\
\hline Bulgaria & 3,072 & 4,425 & $44.07 \%$ \\
\hline Malta & 619 & 836 & $35.22 \%$ \\
\hline Romania & 8,222 & 10,965 & $33.35 \%$ \\
\hline Slovakia & 7,321 & 9,735 & $32.98 \%$ \\
\hline Poland & 26,732 & 35,129 & $31.41 \%$ \\
\hline Czech Republic & 14,523 & 18,944 & $30.45 \%$ \\
\hline Portugal & 8,189 & 10,418 & $27.23 \%$ \\
\hline Luxembourg & 5,992 & 7,212 & $20.36 \%$ \\
\hline Germany & 383,371 & 456,024 & $18.95 \%$ \\
\hline Belgium & 47,154 & 55,434 & $17.56 \%$ \\
\hline Hungary & 10,836 & 12,651 & $16.75 \%$ \\
\hline Austria & 30,881 & 35,816 & $15.98 \%$ \\
\hline Spain & 52,573 & 60,393 & $14.87 \%$ \\
\hline Slovenia & 2,758 & 3,150 & $14.23 \%$ \\
\hline Italy & 126,778 & 141,859 & $11.90 \%$ \\
\hline United Kingdom & 185,635 & 205,744 & $10.83 \%$ \\
\hline Denmark & 31,157 & 33,572 & $7.75 \%$ \\
\hline Netherlands & 80,973 & 86,635 & $6.99 \%$ \\
\hline France & 154,220 & 161,531 & $4.74 \%$ \\
\hline Sweden & 56,169 & 55,974 & $-0.35 \%$ \\
\hline Ireland & 43,878 & 43,578 & $-0.68 \%$ \\
\hline Croatia & 2,987 & 2,824 & $-5.46 \%$ \\
\hline Grecia & 10,106 & 9,506 & $-5.94 \%$ \\
\hline Cyprus & 1,083 & 990 & $-8.54 \%$ \\
\hline Finland & 29,606 & 25,991 & $-12.21 \%$ \\
\hline Mean & $\mathbf{4 7 5 5}$ & $\mathbf{5 3 , 5 8 9}$ & $\mathbf{1 1 . 2 0 \%}$ \\
\hline & & \\
\hline
\end{tabular}

Source: Authors' Compilation

As shown in Table 1, there are wide disparities in the manufacture and trade of European products. Average value-added exports in EU countries exceed 47.5 billion dollars in 2008 and 53.5 billion in 2014, representing an increase of $11.2 \%$. The economic recovery in 2014 is reflected in an increasing commitment to specialization, with countries occupying relevant positions in GVCs to ensure greater competitiveness in the global trade of their products.

Although Germany, the United Kingdom, France and Italy stand out in terms of volume, with far higher value-added exports than the European average, the countries that joined the EU most recently show a very distinct development. With the exception of Cyprus, the accession of the Eastern European countries in 2004 has been accompanied by a gradual process of widespread specialization. Leading the way are countries such as Estonia, Lithuania and Latvia, which have low levels of 
value-added exports but show a promising growth trend; in just six years they have registered increases of more than $45 \%$. Bulgaria and Romania, meanwhile, which joined the EU in 2007, are also clearly making efforts to add value to goods and services traded with third countries.

At the other extreme, lying below the average European growth rate are countries such as the United Kingdom, Denmark, the Netherlands and France. These are nations with an intense export culture and strong presence in GVCs; however, in recent years, their trade in value-added has not kept pace with the growth reported by other European nations, either due to the effects of the economic crisis or because they have a smaller margin for growth than other less developed economies.

In this context, Escaith and Gaudin (2014) analyzed different groups of exporting countries, marking out the Central European countries as small exporters that incorporate a higher content of valueadded into products for international sale, additionally investing in $R \& D$ in order to better position themselves in GVCs. On the other hand, they indicate that the large European economies register a relatively high proportion of both manufactured goods and services. Ireland and Luxembourg, meanwhile, form their own group due to their small size and deep integration in EU value chains.

\section{European Exports according to their Destination: Gravity Model}

Gravity equations in their most basic specification include explanatory variables based on income levels for the countries of origin and destination, their population, and geographical distance as proxy for transport costs, with their origin going back to Tinbergen (1962) and Pöyhönen (1963ab). In this paper, theoretically socio-cultural variables that determine trade relations are included (e.g., sharing a language or border, having colonial ties). Expression of equation (1) is as follows:

$\log \left(\mathrm{X}_{\mathrm{ijt}}\right)=\beta_{0}+\beta_{1} \log \left(\mathrm{D}_{\mathrm{ij}}\right)+\beta_{2} \log \left(\mathrm{Y}_{\mathrm{it}}\right)+\beta_{3} \log \left(\mathrm{Y}_{\mathrm{jt}}\right)$

$+\beta_{4} \log \left(\mathrm{P}_{\mathrm{it}}\right)+\beta_{5} \log \left(\mathrm{P}_{\mathrm{jt}}\right)+\beta_{6} \mathrm{LPI}_{\mathrm{it}}+\beta_{7} \mathrm{LPI}_{\mathrm{jt}}+\beta_{\mathrm{A}} \mathrm{W}_{\mathrm{ij}}+\mathrm{u}_{\mathrm{ijt}}(1)$

where,

$\mathrm{X}_{\mathrm{ijt}}$ : Quantity exported by country $i$ to country $j$ at time $t$ (gross export or add value export)

$\mathrm{D}_{\mathrm{ij}}$ : Distance between country $i$ and country $j$

$\mathrm{Y}_{\mathrm{it}}$ : GDP nominal of country $i$ at time $t$

$\mathrm{Y}_{\mathrm{jt}}$ : GDP nominal of country $j$ at time $t$

$\mathrm{P}_{\mathrm{it}}$ : Population of country $i$ at time $t$

$\mathrm{P}_{\mathrm{jt}}$ : population of country $j$ at time $t$

LPI $_{\mathrm{it}}$ : Logistic Performance Index for country $i$

LPI $_{\mathrm{jt}}$ : Logistic Performance Index for country $j$

$\mathrm{W}_{\mathrm{ij}}$ : Dummy variables (border, official languages, colony).

$\mathrm{u}_{\mathrm{ij}}$ : Standard error

According to equation (1), export volume is a function of economic, geographic, demographic and logistic variables. As an export performance indicator $\left(\mathrm{X}_{\mathrm{ijt}}\right)$ we use the logarithm of value added in exports $(\log \mathrm{VA})$
In this proposal, the original hypothesis is that the included variables have a significant impact on trade, and the signs are coherent with the postulates of economic theory. Distance, as an indication of transport costs, is problematic when assumed to be independent of the mode of transport used and the capitals or economic centres of the country. The effect of distance between countries $\left(\beta_{1}\right)$ should be negative, because closeness promotes more trade.

Theoretically, the Gross Domestic Product (GDP) coefficients of both the exporter and importer $\left(\beta_{2}\right.$ and $\beta_{3}$ ) will be positive, and with more economic value, there is an expectation that exports and imports will be more significant. However, the population coefficient for the exporter $\left(\beta_{4}\right)$ can be positive or negative depending on whether the more populous country exports less due to an absorption effect of domestic production or exports more due to the predominance of technological and logistic variables associated with the level of economic development. In turn, the population coefficient of the importer $\left(\beta_{5}\right)$ also has an ambiguous sign for the same reasons that have been presented above. LPI index provides both qualitative and quantitative measurements, helping to build logistical profiles for countries, and to measure performance throughout the entire supply chain, values of LPI for both exporter and importer are included in the gravity model coefficients $\left(\beta_{6}\right.$ and $\left.\beta_{7}\right)$; a positive sign is expected in both cases. The three qualitative characteristics that are represented by dummy variables (border, language and colonial ties) are expected to have a positive coefficient $\left(\beta_{\mathrm{A}}\right)$ since they encourage bilateral trade relations between countries.

Regarding explanatory variables, distance between countries, expressed in kilometres, has been obtained from CEPII (Centre d'Etudes Prospectives et d'Informations Internationals), serving as a first approximation given the complexity of determining the location of production areas, which are often distributed throughout a given territory. The GDP data (expressed in dollars) and population have been obtained from the United Nations database. The set of dummy variables that characterise countries socially and culturally has also been obtained from CEPII. The World Bank has published the LPI index for 5 years (Arvis et al 2007, 2010, 2012, 2014 and 2016), ranking 150-160 countries and providing an extensive explanation of logistic performance in these countries.

The LPI is built on the basis of a worldwide survey carried out on companies responsible for the transport of goods and for the facilitation of trade globally. The aggregate index is calculated by analyzing six main components, being the indicators the following: customs, infrastructure, international shipments, competence, tracking and timeliness. None of these independently guarantee a good level of logistics performance, and their inclusion is conditioned to empirical studies and extensive interviews carried out with specialists on international freight transport. Each component is defined as follows:

- Customs: measures the efficiency and effectiveness of the customs despatch procedure (speed, simplicity and predictability of customs agencies). All of this is configured through a series of administrative tasks that allow the existing legislation on international trade to be 
implemented and taxes on the import/export of goods and services to be collected.

- Infrastructure: measures the quality of the country's transport and telecommunications infrastructure. It is related to the procedure used for moving the goods to the final consumer, and is not totally controlled by companies due to external factors. However, it is important to measure how organizations cope with the available facilities, being either an advantage or an obstacle that prevents them from being competitive.

- International shipments: measures how easy it is to arrange shipments at competitive prices.

- Logistics quality and competence: measures the competence and quality of logistics services. It shows how certain parties within the organizational structure behave, representing the quality of service to the customer and optimizing the relationship between organizations and consumers.

- $\quad$ Tracking and tracing: measure the tracking and tracing of shipments. It is important to identify the exact location and the route of each consignment up to its delivery to the end customer. All parties in the good's supply chain are involved in this component, and consequently traceability is the result of the activity of the sector as a whole.

- $\quad$ Timeliness: measures the punctuality of shipment delivery times. This is an important factor for consideration, because with the existing high level of competition, failure to comply with delivery schedules is unacceptable. This has influenced the need for increasingly sophisticated computerization processes.

These components cover the various areas that define LPI and it has been proved that they have a greater impact than distance and transport costs (Korinek and Sourdin 2011). Specifically, they include elements of essential logistical value, such as the transparency of processes and their quality, as well as the predictability and reliability of services. The indicators have been added and properly weighted, receiving a score of 1 to 5 where the higher value represents better logistics.

The total sample consists of the EU-28 countries as exporters, with their value-added representing the dependent variable, while the importers are Australia, Brazil, Canada, Switzerland, China, Indonesia, India, Japan, Korea, Mexico, Norway, Russia, Turkey and the USA. The research has been carried out with statistical data sourced from WIOD, and the choice of these importers is based on the information available therein. The total sample of European countries has then been divided into two groups according to the relative importance of their value-added trade destinations. The main buyer is the USA, which ranks in either first or second place for all European countries. The classification has therefore been made depending on which country is the second most important (or in some cases, most important) destination; namely, Russia or China. The resulting groups for 2008 are shown in Table 2.
Table 2: Countries by Importance of Destination in 2008 ( $\%$ of Total Value-Added Exports)

\begin{tabular}{|c|c|c|c|c|c|}
\hline & \multicolumn{2}{|c|}{ GROUP 1} & & \multicolumn{2}{|c|}{ GROUP 2} \\
\hline & Russia & USA & & China & USA \\
\hline Slovakia & 34.54 & 19.92 & Germany & 15.42 & 28.64 \\
\hline Estonia & 30.46 & 21.98 & Netherlands & 13.73 & 33.02 \\
\hline Lithuania & 29.77 & 26.69 & France & 12.87 & 32.06 \\
\hline Poland & 27.56 & 20.73 & Austria $^{*}$ & 12.7 & 27.23 \\
\hline Latvia & 22.74 & 24.31 & Malta & 12.19 & 27.73 \\
\hline Chez Republic & 20.36 & 23.54 & Netherlands ${ }^{*}$ & 12.11 & 24.88 \\
\hline Finland & 19.47 & 24.30 & Sweden ${ }^{*}$ & 11.08 & 27.33 \\
\hline Slovenia & 15.78 & 25.98 & Belgium & 11.02 & 34.85 \\
\hline Hungary & 15.17 & 27.74 & Luxembourg ${ }^{*}$ & 10.53 & 21.56 \\
\hline Cyprus & 11.28 & 48.11 & Italy & 10.13 & 28.71 \\
\hline Bulgaria & 9.56 & 21.62 & Greece $^{*}$ & 9.79 & 31.60 \\
\hline & & & Portugal ${ }^{*}$ & 9.54 & 37.50 \\
\hline & & & Croatia & 9.07 & 36.05 \\
\hline & & & Spain & 9.02 & 33.28 \\
\hline & & & Ireland & 8.52 & 53.94 \\
\hline & & & United Kingdom* & 8.22 & 43.05 \\
\hline & & & Romania $^{*}$ & 7.81 & 22.85 \\
\hline
\end{tabular}

Source: Authors' Compilation - Data from WIOD

Note: $(*)$ For these countries, China is the third destination in importance

Table 2 shows that, the USA absorbs the largest volume of intermediate goods from the EU-28. The North American country has become the primary destination, or sometimes the second most important destination, for European value-added exports. As a percentage of all EU value-added exports, values range between $19.9 \%$ and $53.9 \%$, with Slovakia registering the lowest percentage and Ireland the highest. Given the importance of trade with the USA, any new trade agreement that facilitates openness and the transit of goods between these two great powers, in other words, an EU-USA Free-Trade Area, would open up a new phase in trade relations between the two sides of the Atlantic.

The second most important destinations are Russia and China. Since 1994, Russia has been party to an EU Partnership and Cooperation Agreement, leading to an ongoing growth in trade relations between the two. The results show the prominence of Slovakian, Estonian and Lithuanian exports to Russia $(34.54 \%, 30.46 \%$ and $29.77 \%$, respectively, of their total foreign trade goes to Russia), as their proximity represents a strong boost to trade between these countries.

China is also a significant importer: due to its status as an emerging economy. It uses many products and materials from European countries, most notable of which is Germany, with $15.42 \%$ of its exports destined for the Asian giant. The opening up of China to trade in 1978 resulted in a staggering increase in relations with the different nations that currently make up the EU. In just over 30 years, the volume traded between Europe and China has multiplied by 40 , and in 2003 it exceeded 
100 billion euros for the first time, according to official statistics.

Presented below is the distribution of destinations in 2014, by which time European countries are in a very different phase of the economic cycle (Table $3)$.

Table 3: Distribution of Countries by Importance of Trade Destination in 2014 (\% of Total Value-Added

Exports)

\begin{tabular}{|c|c|c|c|c|c|}
\hline & \multicolumn{2}{|c|}{ GROUP 1} & & \multicolumn{2}{|c|}{ GROUP 2} \\
\hline & Russia & USA & & China & USA \\
\hline Estonia & 32.69 & 15.87 & Slovakia & 23.37 & 21.35 \\
\hline Latvia & 32.52 & 15.12 & Germany & 22.74 & 27.24 \\
\hline Lithuania & 32.42 & 26.70 & Denmark & 20.18 & 22.33 \\
\hline Cyprus & 24.99 & 21.57 & Bulgaria $^{*}$ & 18.90 & 18.06 \\
\hline Poland & 20.41 & 23.53 & Netherlands & 18.63 & 31.66 \\
\hline Chez Republic & 20.09 & 21.67 & France & 18.14 & 29.50 \\
\hline & & & Luxembourg* & 18.00 & 19.02 \\
\hline & & & Austria & 17.53 & 26.25 \\
\hline & & & Hungary & 17.22 & 30.03 \\
\hline & & & Finland & 16.88 & 25.48 \\
\hline & & & Belgium & 16.33 & 34.44 \\
\hline & & & Croatia & 16.27 & 30.59 \\
\hline & & & Portugal & 15.98 & 30.94 \\
\hline & & & Romania & 15.50 & 24.68 \\
\hline & & & Slovenia & 15.31 & 23.23 \\
\hline & & & Greece $^{*}$ & 15.00 & 17.34 \\
\hline & & & United Kingdom & 14.92 & 38.05 \\
\hline & & & Sweden ${ }^{*}$ & 14.40 & 22.67 \\
\hline & & & Spain & 13.81 & 27.79 \\
\hline & & & Italy & 13.45 & 28.87 \\
\hline & & & Ireland & 12.92 & 46.59 \\
\hline & & & Malta & 11.20 & 16.73 \\
\hline
\end{tabular}

Source: Authors' Compilation - Data from WIOD

Note: (*) For these countries, China is the third destination in importance

An analysis of 2014 reveals some significant differences compared to 2008. Slovakia, Finland, Slovenia, Hungary and Bulgaria, which in 2008 sent between $34.54 \%$ and $9.56 \%$ (corresponding to Slovakia and Bulgaria, respectively) of their value-added to Russia, have shifted towards China, with values ranging between $23.37 \%$ for Slovakia and $15.31 \%$ for Slovenia. The growth of the Asian giant has meant that it has improved its position with respect to Russia. Deemed "the world's factory", China has become one of the largest buyers of European value-added. As a result,
China and the USA are the top two destinations for $78 \%$ of EU-28 counties.

The results also confirm that countries which have China as a primary destination in 2008 continue to do so in 2014. In fact, the importance of this destination has even increased overall, with the exception of Malta, which registers a drop of just over one percentage point. China has consolidated its position as a recipient of European goods; as a consequence, the EU should promote trade policies that foster the relationship with this Asian country, since an increase in its purchases will obviously help boost European economic growth.

The analysis of the determinants of bilateral trade between the EU and its main destinations (the USA, Russia and China) was carried out for 2008 and 2014, and the total sample was divided according to whether the primary destinations were the USA and Russia (Group 1) or the USA and China (Group 2), as shown in Tables 2 and 3. The other importers are the countries provided by the WIOD database that are not part of the EU. Table 4 shows the size of each of the six samples analysed, while Tables A1-A6 in the appendix present the main statistics for all six samples.

Table 4: Sample Size according to Groups of

Countries

\begin{tabular}{|c|c|c|c|}
\hline & $\begin{array}{c}\text { Group 1 } \\
\text { USA-Russia }\end{array}$ & $\begin{array}{c}\text { Group 2 } \\
\text { USA-China }\end{array}$ & $\begin{array}{c}\text { Total } \\
\text { sample }\end{array}$ \\
\hline 2008 & $\begin{array}{c}154 \\
(39.28 \%)\end{array}$ & $\begin{array}{c}238 \\
(60.71 \%)\end{array}$ & $\begin{array}{c}392 \\
(100 \%)\end{array}$ \\
\hline 2014 & $\begin{array}{c}84 \\
(21.42 \%)\end{array}$ & $\begin{array}{c}308 \\
(78.57 \%)\end{array}$ & $\begin{array}{c}392 \\
(100 \%)\end{array}$ \\
\hline
\end{tabular}

Source: Authors' Compilation

The size of the samples indicates once again the importance of this giant Asian economy as the final destination for European intermediate goods, to the detriment of Russia. The change in the economic cycle that European countries underwent in 2014 has been reflected in a search for trading partners that support the use of their intermediate goods for assembly, be it thanks to the quality of these goods and/or superior trade conditions between the countries.

\section{Results: Determinants of European Value-Added Exports}

In line with the main aims of this paper, a gravity equation has been estimated to reveal any potential changes in the determinants of value-added exports resulting not only from a change in the final destination, but also due to the different economic situation. The results shown in Figure 1 have been standardized so that the variables used all have the same measurement units, which allows for a meaningful comparison of the coefficients. 


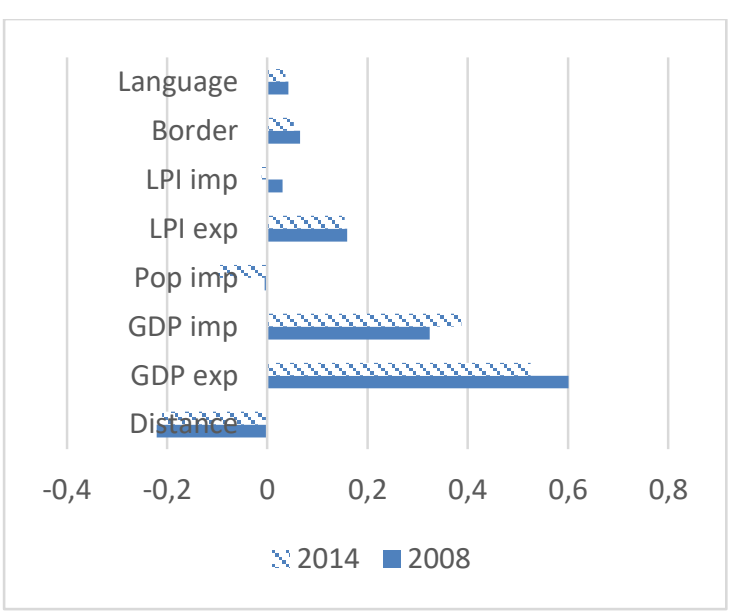

Figure 1. Significant Determinants of Value Added in Exports for UE-28 Economies

Source: Authors' Compilation

Note: The regression results are in Table A7 in annex. No significance was found betwen exporter population and colony.

The independent variables explain more than $93 \%$ of value-added exports in 2008 , and more than $91 \%$ in 2014. In addition, the signs of the coefficients that were found to be significant are in line with those established by economic theory of international trade. In both estimates, the GDP of the exporter is the most important variable; its coefficient is positive, confirming the direct relationship between a country's level of domestic production and its export volume. With respect to the importer, its GDP is also relevant, although not as markedly so as that of the exporter; there is a positive correlation between the wealth of the importer country and its trade flows. The third most important variable is distance, indicating the difficulties inherent in the distance separating trading partners: the farther countries are from one another, the lower their export volume. Population is only significant for the importer in 2014, with the negative sign indicating that the most populated countries import the least value-added, since they primarily rely on domestic production.

A priori, logistics should foster the trade in products between countries, as it not only facilitates international trade but also improves the transport and reception of goods, among other aspects. In this study, the LPI index, representing logistics, is only significant for the exporter; that is, the trade facilities provided by the country selling the goods play a decisive role in its ability to find buyers for its products. The aspects rated in this index are as follows: the level of infrastructure, the efficiency of the customs clearance process, the timeliness of shipments; the ease of arranging competitively priced shipments, the quality of logistics services, and the availability of a good system for tracking and tracing consignments. Finally, the dummy variables, border and language, are influential in the two years analysed and have a positive effect.

Next, the estimates are carried out by separating the sample into groups of countries according to the destination of their value-added exports, as defined in Table 2. The results for 2008 are shown in Table 5, with countries' allocation to Group 1 or Group 2 depending on whether their second most important (or sometimes most important) destination for its exports is Russia or China, respectively.

Table 5: Estimated Coefficients for Destination Groups in 2008

\begin{tabular}{|l|c|c|}
\cline { 2 - 3 } \multicolumn{1}{c|}{} & $\begin{array}{c}\text { Group 1 } \\
\text { USA-Russia }\end{array}$ & $\begin{array}{c}\text { Group 2 } \\
\text { USA-China }\end{array}$ \\
\hline Distance & $-0.284^{* * *}$ & $-0.194^{* * *}$ \\
\hline GDP export & $0.536^{* * *}$ & $0.492^{* * *}$ \\
\hline GDP import & $0.372^{* * *}$ & $0.288^{* * *}$ \\
\hline Pop export & $-0.069^{*}$ & 0.053 \\
\hline Pop import & $-0.052^{*}$ & 0.030 \\
\hline LPI export & -0.005 & $0.227^{* * *}$ \\
\hline LPI imp & -0.022 & $0.070^{* * *}$ \\
\hline Border & 0.045 & $0.044^{* * *}$ \\
\hline Language & $-0.069^{* * *}$ & $0.046^{* * *}$ \\
\hline Colony & 0.019 & -0.011 \\
\hline Observations & 154 & 238 \\
\hline$R^{2}$ Adj & 0.911 & 0.937 \\
\hline \multicolumn{2}{|c|}{$* * * p$-value $<0.01 ; * * p$-value $<0.05 ; * p$-value $<0.1$}
\end{tabular}

Source: Authors' Compilation

As the results show, the distance coefficients for European countries whose main destinations are Russia and the USA are higher than for countries whose main destinations are China and the USA. This indicates that, each kilometre of distance between buyer and seller places greater restrictions on trade for the former. Indeed, this result is in line with the ease and cost of transporting goods and with the interpretation of the coefficients obtained for the LPI.

The logistics of the exporter and the importer (LPI) have different effects in each group: the coefficients are significant and positive only in Group 2, with this group belonging to a group of countries whose level of logistics development is above the European average, according to the classification by Puertas et al. (2014). At the other extreme, however, Group 1 comprises countries with deficiencies in logistics and so their trade is not influenced by this variable, a fact that explains the lack of significance of these variables.

The wealth of the exporting and importing country continue to be the most important variables in determining value-added exports, and this result is even more marked in the countries comprising Group 1. As they are less developed countries, their level of wealth is crucial with respect to the volume traded.

Table 6 below presents the standardized coefficients of the gravity models for the two groups of exporting countries in 2014 . 
Table 6: Estimated Coefficients for Destination

\section{Groups in 2014}

\begin{tabular}{|lc|c|}
\cline { 2 - 3 } \multicolumn{1}{c|}{} & \multicolumn{1}{c}{$\begin{array}{c}\text { Group1 } \\
\text { USA-Russia }\end{array}$} & $\begin{array}{c}\text { Group 2 } \\
\text { USA-China }\end{array}$ \\
\hline Distance & $-0.314^{* * *}$ & $-0.189^{* * *}$ \\
\hline GDP export & $0.731^{* * *}$ & $0.401^{* * *}$ \\
\hline GDP import & $0.452^{* * *}$ & $0.368^{* * *}$ \\
\hline Pop export & -0.249 & $0.133^{*}$ \\
\hline Pop import & $-0.173^{* * *}$ & $-0.077^{* * *}$ \\
\hline LPI export & $0.103^{* * *}$ & $0.201^{* * *}$ \\
\hline LPI imp & $-0.082^{* *}$ & 0.009 \\
\hline Border & 0.003 & $0.041^{* * *}$ \\
\hline Language & $-0.081^{* * *}$ & $0.042^{* * *}$ \\
\hline Colony & 0.050 & -0.014 \\
\hline Observations & 84 & 308 \\
\hline$R^{2}$ Adj & 0.935 & 0.908 \\
\hline
\end{tabular}

*** p-value $<0.01 ; * * p$-value $<0.05 ; *$-value $<0.1$

Source: Authors' Compilation

In terms of logistics, notable changes can be seen with respect to 2008. In the exporting countries of Group 1, whose main destinations are the USA and Russia, logistics assumes a significant role. The European economic crisis itself and the need to export have had a favorable influence on the changes detected, but also that the adoption of European policy is resulting in these European countries being remarkably successful in this respect. Issues such as the modernization of customs services and the widespread acceptance of the figure of the authorised economic operator, the single foreign trade windows at ports, the incorporation of global private operators into port terminal management, the development of port community systems and, in turn, the ICTs at the services of the logistics chain, among other initiatives, have prompted greater competence, more regular shipping lines and have permitted to overcome the traditional model of the freight forwarder in favor of a mature model. In addition, the inclusion of these countries in the Trans-European Transport Networks has contributed to the provision of infrastructure that logically culminates in enhanced logistics performance.

Along with logistics, in Group 1 distance, exporter GDP and importer GDP gain in importance as determinants of value-added exports compared to the results for 2008. For Group 2 countries, however, only importer GDP assumes greater relevance. This may be due to the fact that the change in the economic cycle has a greater impact on Eastern European countries, with these countries making notable efforts to increase their value-added trade in an attempt to adapt to the new global production model.

\section{Conclusion and Recommendations}

In the empirical study carried out, it has been shown that gravity models are a useful tool for quantifying the relative importance of the determinants of value-added exports, with European countries classified according to their main trade destinations. The two years selected for analysis allow the effect of the economic cycle on foreign trade patterns to be identified. The results obtained show changes in European countries' trade patterns.

In the first place, the vast majority of Eastern European countries, which represent more recent additions to the EU, have opted for ever-greater participation in GVCs, increasing their value-added trade by around $45 \%$ in just six years. These are countries with lower levels of economic development seeking active integration in cross-border production processes, in which other European countries such as Germany, the United Kingdom, France and Italy have strengthened their participation.

Secondly, the economic recovery of 2014 has meant that distance does not pose a barrier to trade. As a result, European countries have replaced Russia with China as one of their principal destinations for valueadded exports. This indicates that the Asian giant and the USA have become the main assemblers of intermediate goods from Europe.

Thirdly, although the contrasting economic circumstances in 2008 and 2014 are not reflected in the determinants of European value-added exports, when the analysis is carried out according to trade destinations, different patterns are observed. The changes in the economic cycle have had a greater effect on countries whose main destinations are Russia and the USA. All significant variables show greater explanatory power for trade in 2014. Furthermore, this economic growth has also resulted in logistics becoming more relevant in terms of boosting trade.

In summary, the results of this empirical study help build up a picture of trade that more closely reflects the current reality. By replacing gross exports with valueadded exports, the double counting problem in official statistics is avoided, and the varying levels of European participation in GVCs is revealed. Trade policies and international free trade agreements should take into account this new reality, where every country is assigned what it actually exports. The variables used in the research do not favor the analysis of the economic policies adopted during these years. Future research will include information on tariff barriers, carrying out a more extensive analysis over time that will make it possible to detect possible changes that have occurred as a result of the different policies adopted by European countries. 


\section{References}

Arvis, J.F., Mustra. M., Ojala, L., Shepherd, B. and D. Saslavsky. 2010. Connecting to Compete 2010: Trade Logistics in the Global Economy--The Logistics Performance Index and Its Indicators. The World Bank, Washington DC.

Arvis, J.F., Mustra, M., Ojala, L., Shepherd, B. and D. Saslavsky. 2012. Connecting to Compete 2012: Trade Logistics in the Global Economy--The Logistics Performance Index and Its Indicators. The World Bank, Washington DC.

Arvis, J.F., Mustra, M., Panzer, J., Ojala, L. and T. Naula. 2007. Connecting to Compete 2017: Trade Logistics in the Global Economy--The Logistics Performance Index and Its Indicators. The World Bank, Washington DC.

Arvis, J.F., Saslavsky, D., Ojala, L., Shepherd, B., Busch, C. and A. Raj. 2014. Connecting to Compete 2014: Trade Logistics in the Global Economy--The Logistics Performance Index and Its Indicators. The World Bank, Washington DC.

Arvis, J.F., Saslavsky, D., Ojala, L., Shepherd, B., Busch, C., Raj, A. \& T. Naula. 2016. Connecting to Compete 2016: Trade Logistics in the Global Economy--The Logistics Performance Index and Its Indicators. The World Bank, Washington DC.

Daudin, G., Rifflart, C. and D. Schweisguth. 2011. "Who produces for whom in the World Economy?". Canadian Journal of Economics 44 (4): 140337.

Dedrick, J., Kraemer, L. and G. Linden. 2010. "Who Profits From Innovation in Global Value Chains?: A Study of the iPod and Notebook PCs". Industrial and Corporate Change 19(1): 81-116.

Escaith, H. and H. Gaudin. 2014. "Clustering ValueAdded Trade: Structural and Policy Dimensions". World Trade Organization Economic Research and Statistics Division Staff Working Paper No. ERSD-2014-08. Paris.

Felipe, J. and U. Kumar. 2012. "The Role of Trade Facilitation in Central Asia: A Gravity Model". Eastern European Economics 50(4): 5-20.

Grossman, G. and E. Rossi-Hansberg. 2008. "Trading tasks: A simple theory of offshoring". American Economic Review 98(5): 1978-97.

Hertel, T. and T. Mirza. 2009. "The Role of Trade Facilitation in South Asian Economic Integration". In Australian Government ADB (Eds.), Study on Intraregional Trade and Investment in South Asia (pp. 12-39). Mandaluyong City; Asian Development Bank
Hummels, D., Ishii, J. and K. Yi. 2001. "The Nature and Growth of Vertical Specialization in World Trade". Journal of International Economics 54(1): 75-96.

Johnson, R. and G. Noguera. 2012. "Accounting for Intermediates: Production Sharing and Trade in Value Added. Journal of International Economics 86(2): 224-36.

Koopman, R., Powers, W., Wang, Z. and S.J Wei. 2010. "Given Credit Where Credit Is Due: Tracing Value Added in Global Production Chains". NBER Working Paper 16426. Cambridge, MA.

Koopman, R., Wang, Z. and S.J. Wei. 2008. "How Much Chinese Exports if Really Made in ChinaAssessing Foreign and Domestic Value-Added in Gross Exports?". NBER Working Paper 14109. Washington, DC.

Koopman, R., Wang, Z. and S.J. Wei. 2012. "Estimating Domestic Content in Exports When Processing Trade Is Pervasive". Journal of Development Economics. 99(1): 178-89.

Koopman, R., Wang, Z. and S.J. Wei. 2014. "Tracing Value-Added and Double Counting in Gross Export". American Economic Review. 104(2): 459-494.

Korinek, J. and P. Sourdin. 2011. "To What Extent Are High-Quality Logistics Services Trade Facilitating?". OECD Trade Policy Working Papers 108. OECD Publishing.

Leamer, E. 2006. Analyzing the U.S. Content of Imports and the Foreign Content of Exports. The National Academies Press. Washington DC.

Narayanan, B. and T. L. Walmsley. 2008. Global Trade, Assistance, and Production: The GTAP 7 Data Base. Center for Global Trade Analysis, Purdue University, West Lafayette.

Pöyhönen, P. 1963a. "A Tentative Model for the Volume of Trade between Countries". WeltwirschaftlichesArchiv 16: 93-99.

Pöyhönen, P. 1963b. "Toward a General Theory of International Trade". EkonomiskaSamfundetsTidskrift 16: 69-78.

Puertas, R., Marti, L. and L. García 2014. "Logistic Performance and Export Competitiveness: European Experience”. Empirica 41: 467-480.

Stehrer, R., Foster, N. and G. De Vries 2012. "Value added and factors in trade: A comprehensive approach". Vienna Institute for International Economic Studies Working Paper 80.

Tinbergen, J. 1962. Shaping the World Economy: Suggestions for International Economic Policy. The Twentieth Century Inc, New York. 
Timmer, M. 2012. "The World Input-Output Database (WIOD): Contents, Sources and Methods". WIOD Working Paper, 10

Timmer, M.P., Dietzenbancher, E., Los, B., Stehrer, R. and G.J. Vries, 2015. "An illustrated User Guide to the World Input-Ouput Database: The case of Global Automotive Production". Review of International Economics 23(3): 575605 .

\section{Annex}

Table 1A: Main Statistics 2008 Total Sample

\begin{tabular}{|l|cccc|}
\hline & Max & Min & Mean & $\begin{array}{c}\text { Standard } \\
\text { Error }\end{array}$ \\
\hline VA (1) & $109,803.1$ & 7 & $3,399.0$ & $9,177.8$ \\
Distance & $18,190.6$ & 252 & $6,981.1$ & $4,197.1$ \\
GDP exp (1) & $2,923,573$ & 8978 & 653,039 & 933,105 \\
GDP imp (1) & $14,718,582$ & 461947 & $2,566,423$ & $3,642,262$ \\
Pop exp (2) & 82.2 & 0.4 & 17.5 & 22.7 \\
Pop imp (2) & 1,326 & 4.7 & 273.6 & 413.6 \\
LPI exp & 4.1 & 2.8 & 3.5 & 0.4 \\
LPI imp & 4 & 2.6 & 3.5 & 0.5 \\
\hline
\end{tabular}

Note (1): millions of USA\$

Note (2) millions of persons

Source: Authors' Compilation - Data from WIOD

Table 2A: Main Statistics 2008 for Group 1

\begin{tabular}{|l|cccc|}
\hline & Max & Min & Mean & $\begin{array}{c}\text { Standard } \\
\text { Error }\end{array}$ \\
\hline VA (1) & 672 & $7,367.5$ & 11.5 & $1,198.8$ \\
Distance & $6,765.7$ & $16,152.8$ & 377.9 & $4,197.9$ \\
GDP exp (1) & 141,127 & 533,806 & 24,165 & 150,267 \\
GDP imp (1) & $2,566,423$ & $14,718,582$ & 461,946 & $3,649,481$ \\
Pop exp (2) & 7.9 & 38.1 & 0.8 & 10.1 \\
Pop imp (2) & 273.7 & $1,326.7$ & 4.8 & 414.5 \\
LPI exp & 3.2 & 3.9 & 2.8 & 0.3 \\
LPI imp & 3.5 & 4 & 2.6 & 0.5 \\
\hline
\end{tabular}

Note (1): millions of USAS

Note (2) millions of persons

Source: Authors' Compilation - Data from WIOD

Table 3A: Main Statistics 2008 for Group 2

\begin{tabular}{|l|cccc|}
\hline & Max & Min & Mean & $\begin{array}{c}\text { Standard } \\
\text { Error }\end{array}$ \\
\hline VA (1) & 5163.5 & $109,803.1$ & 6,9 & $11,405.2$ \\
Distance & $7,120.5$ & $18,190.6$ & 252.3 & $4,199.5$ \\
GDP exp (1) & 984,276 & $2,923,573$ & 8,977 & $1,068,368$ \\
GDP imp (1) & $2,566,423$ & $14,718,582$ & 461,946 & $3,645,279$ \\
Pop exp (2) & 23.9 & 82.3 & 0.4 & 26.3 \\
Pop imp (2) & 273.7 & $1,326.7$ & 4.8 & 414.0 \\
LPI exp & 3.6 & 4.1 & 2.8 & 0.5 \\
LPI imp & 3.5 & 4 & 2.6 & 0.5 \\
\hline
\end{tabular}

Note (2) millions of persons

Source: Authors' Compilation - Data from WIOD
Table 4A: Main Statistics 2014 Total Sample

\begin{tabular}{|l|cccc|}
\hline & Max & Min & Mean & $\begin{array}{c}\text { Standard } \\
\text { Error }\end{array}$ \\
\hline VA (1) & $124,226.8$ & 7,5 & 3827.8 & $10,699.7$ \\
Distance & $18,190.6$ & 252.3 & 6981.1 & $4,197.1$ \\
GDP exp (1) & $3,879,276$ & 10,737 & 663,374 & $1,013,248$ \\
GDP imp (1) & $17,393,103$ & 498,339 & $3,436,487$ & $4,611,704$ \\
Pop exp (2) & 80.6 & 0.4 & 18.1 & 22.9 \\
Pop imp (2) & $1,369.4$ & 5.1 & 288.6 & 436.4 \\
LPI exp & 4.2 & 2.8 & 3.6 & 0.4 \\
LPI imp & 4 & 2.6 & 3.5 & 0.4 \\
\hline
\end{tabular}

Note (1): millions of USA\$

Note (2) millions of persons

Source: Authors' Compilation - Data from WIOD

Table 5A: Main Statistics 2014 for Group 1

\begin{tabular}{|l|cccc|}
\hline & Max & Min & Mean & $\begin{array}{c}\text { Standard } \\
\text { Error }\end{array}$ \\
\hline VA (1) & 788.3 & $7,213.4$ & 12.9 & $1,403.8$ \\
Distance & $6,706.1$ & $16,097.5$ & 377.9 & $4,211.0$ \\
GDP exp (1) & 147,066 & $545,151.8$ & 23,307 & 190,513 \\
GDP imp (1) & $3,436,48$ & $17,393,103$ & 498,339 & $4,633,48$ \\
Pop exp (2) & 7 & 38.6 & 0.9 & 1 \\
Pop imp (2) & 288.6 & $1,369.4$ & 5.1 & 438.4 \\
LPI exp & 3.4 & 3.7 & 3 & 0.2 \\
LPI imp & 3.5 & 4 & 2.6 \\
\hline \multicolumn{5}{c}{ Note (1): millions of USA \$ } \\
Source: Authors' Compilation - Data from WIOD
\end{tabular}

Table 6A: Main Statistics 2014 for Group 2

\begin{tabular}{|l|cccc|}
\hline & Max & Min & Mean & $\begin{array}{c}\text { Standard } \\
\text { Error }\end{array}$ \\
\hline VA (1) & 4656.7 & $124,226.8$ & 7.5 & $11,918.8$ \\
Distance & $7,056.1$ & $18,190.6$ & 252.3 & $4,197.1$ \\
GDP exp (1) & 804,186 & $3,879,276$ & 10,737 & $1,097,698$ \\
GDP imp (1) & $3,436,487$ & $17,393,103$ & 498,339 & $4,613,314$ \\
Pop exp (2) & 20.5 & 80.6 & 0.4 & 24.4 \\
Pop imp (2) & 288.6 & $1,369.4$ & 5.1 & 436.5 \\
LPI exp & 3.7 & 4.2 & 2.8 & 0.4 \\
LPI imp & 3.5 & 4 & 2.6 & 0.4 \\
\hline
\end{tabular}

Source: Authors' Compilation - Data from WIOD 
Table 7A: Estimated Coefficients of the Gravity Equation for the Total Sample

\begin{tabular}{|l|c|c|}
\hline & 2008 & 2014 \\
\hline Distance & $-0.221^{* * *}$ & $-0.210^{* * *}$ \\
\hline GDP export & $0.601^{* * *}$ & $0.525^{* * *}$ \\
\hline GDP import & $0.324^{* * *}$ & $0.387^{* * *}$ \\
\hline Pop export & 0.002 & 0.070 \\
\hline Pop import & -0.005 & $-0.099^{* * *}$ \\
\hline LPI export & $0.159^{* * *}$ & $0.154^{* * *}$ \\
\hline LPI import & $0.030^{*}$ & -0.011 \\
\hline Border & $0.065^{* * *}$ & $0.053^{* * *}$ \\
\hline Language & $0.042^{* * *}$ & $0.036^{* * *}$ \\
\hline Colony & -0.020 & 0.014 \\
\hline Observations & 392 & 392 \\
\hline$R^{2}$ Adj & 0.934 & 0.917 \\
\hline
\end{tabular}

Note: $* * * p$-value $<0.01 ; * * p$-value $<0.05 ; *$ p-value $<0.1$

Source: Authors' Compilation - Data from WIOD 